\title{
POTENSI TANAMAN MANGROVE DAN ASOSIASINYA SEBAGAI PENGHASIL ANTIOKSIDAN PADA BUDIDAYA PERIKANAN
}

\author{
Muliani dan Muharijadi Atmomarsono \\ Balai Penelitian dan Pengembangan Budidaya Air Payau \\ Jl. Makmur Dg. Sitakka No. 129, Maros 90512, Sulawesi Selatan \\ E-mail: mulianim@yahoo.com
}

(Naskah diterima: 29 Januari 2014; Revisi final: 9 Mei 2014; Disetujui publikasi: 3 Juni 2014)

\begin{abstract}
ABSTRAK
Penelitian ini bertujuan untuk mengetahui potensi tanaman mangrove dan asosiasinya sebagai penghasil bahan antioksidan pada budidaya perikanan. Penelitian dilaksanakan pada bulan Maret hingga Oktober 2014 di Balai Penelitian dan Pengembangan Budidaya Air Payau (BPPBAP). Pengumpulan sampel mangrove dan asosiasinya dilakukan di derah pertambakan Sulawesi Selatan. Skrining bahan herbal mangrove dan asosiasinya sebagai penghasil bahan antioksidan dilakukan dengan metode mikrowellplate assay. Standar positif yang digunakan adalah Vitamin C, sedangkan untuk mengevaluasi aktivitas free radical scavening (antioksidan) dari ekstrak mangrove digunakan DPPH $\left(\mathrm{C}_{10} \mathrm{H}_{12} \mathrm{~N}_{5} \mathrm{O}_{6}\right)$. Keberadaan senyawa antioksidan dalam ekstrak mangrove ditandai dengan adanya perubahan reaksi warna pink menjadi kuning. Hasil penelitian menunjukkan bahwa hasil uji aktivitas antioksidan terhadap 182 sampel, $105(58,33 \%)$ sampel di antaranya positif mengandung antioksidan. Dari 105 sampel yang positif antioksidan, $66(62,86 \%)$ sampel adalah tanaman mangrove dan $39(37,14 \%)$ sampel adalah asosiasinya. Berdasarkan lokasi pengambilan dari 105 sampel yang positif antioksidan, sampel terbanyak (32,34\%) dari Kabupaten Pangkep, diikuti dari Kabupaten Bone (24,76\%); Kabupaten Maros (20,0\%); Kabupaten Luwu Timur (16,19\%); dan Kabupaten Takalar (6,67\%). Hal ini menunjukkan bahwa tanaman mangrove dan asosiasinya sangat berpotensi sebagai penghasil antioksidan yang dapat digunakan pada budidaya perikanan.
\end{abstract}

KATA KUNCl: antioksidan, herbal mangrove, asosiasi mangrove, DPPH, vitamin C

ABSTRACT: $\quad$ Potency of mangrove and its association plants as antioxidant source for aquaculture. By: Muliani and Muharijadi Atmomarsono

Study to determine which mangroves and mangrove association plants have antioxidant used for aquaculture was conducted at the Research Institute for Coastal Aquaculture (RICA) from March to October 2014. Mangrove and its association plants were collected from brackishwater pond area in South Sulawesi. Screening of mangrove and its association herbs as antioxidant source was done by microwellplate assay method. used are Vitamin $C$ was used as positive standard, while DPPH $\left(\mathrm{C}_{10} \mathrm{H}_{12} \mathrm{~N}_{5} \mathrm{O}\right.$ ) was used for evaluating the activity of free radical scavening (antioxidants) of mangrove extract. The existence of antioxidant compounds in mangrove extract was determined by the color change from pink to yellow. The results showed that $105(58.33 \%)$ of 182 herb samples had antioxidant activity, where 66 (62.86\%) samples were originated from mangrove plants and $39(37.14 \%)$ samples were originated from mangrove association. The highest number of samples containing antioxidant were collected from Pangkep (32.34\%), followed by Bone (24.76\%), Maros (20.0\%), Luwu Timur (16.19\%), and Takalar (6.67\%). This shows that mangrove and its association have potency as antioxidant source used for aquaculture.

KEYWORDS: antioxidant, mangrove herb, mangrove association, DPPH, vitamin C

\section{PENDAHULUAN}

Mangrove menjadi salah satu ekosistem pesisir yang sangat penting karena memiliki fungsi ekologis yakni sebagai pelindung alami pantai dari abrasi, mempercepat sedimentasi, mengendalikan intrusi air laut, dan melindungi daerah di belakang mangrove dari gelombang tinggi dan angin kencang, tempat memijah, mencari makan, dan berlindung bagi ikan, udang, kepiting, dan biota laut lainnya. Beberapa tahun terakhir ini, mangrove mulai dikenal dan dikembangkan sebagai bahan makanan, minuman, obat-obatan, dan pewarna alami yang memiliki nilai ekonomi yang cukup tinggi. Selain itu juga, ekosistem mangrove di berbagai daerah telah banyak dijadikan 
sebagai obyek ekowisata yang dapat memberikan kontribusi terhadap pendapatan daerah tersebut. Fungsi biologis dan fungsi ekonomi dari hutan mangrove dalam hal ini tanaman mangrove dan asosiasinya akan berjalan dengan sempurna jika keberadaannya tetap terjaga secara lestari.

Beberapa jenis daun mangrove dan tanaman asosiasi mangrove telah diidentifikasi menghasilkan bioaktif sebagai sumber bakterisida dan telah diuji efektivitasnya terhadap penyakit bakterial secara laboratoris. Salah satu tanaman asosiasi mangrove yang keberadaannya perlu dilestarikan adalah tanaman kopasanda, Euphatorium inolifolium. Tanaman ini tersebar luas di daerah dataran rendah hingga daerah estuarin dan tumbuh berasosiasi dengan tanaman mangrove. Ekstrak daun kopasanda dapat berfungsi sebagai bakterisida terhadap bakteri vibrio. Muliani et al. (2005) telah melaporkan, bahwa ekstrak kopasanda pada konsentrasi $1.000 \mathrm{mg} / \mathrm{L}$ adalah yang terbaik. Asosiasi mangrove lainnya seperti daun baru-baru Osbornia octodanta juga mengandung bahan aktif 2 heptanamin-6methylamino- 6 methylin yang aktif menghambat pertumbuhan V. harveyi (Muliani et al., 2005).

Tanaman mangrove dan asosiasinya sebagai bahan antibakteri untuk penanggulangan penyakit pada budidaya perikanan juga telah banyak dilaporkan Revathi et al., 2013; Sasidhar et al., 2013). Beberapa tanaman mangrove yang mempunyai nilai ekonomis tinggi dan telah diketahui mengandung bakterisida di antaranya adalah Rhizophora mucronata (Baskaran \& Mohan, 2012; Mulyani et al., 2013). Selain sebagai antibakteri, tanaman mangrove dan asosiasinya juga sudah mulai dikaji untuk pencegahan penyakit virus pada budidaya perikanan, di antaranya untuk WSSV pada udang (Abed et al., 2013; Chakraborty \& Ghosh, 2014, Chakrabortyet al., 2014). Potensi mangrove dan asosiasinya sebagai bahan penghasil antioksidan juga mulai dikaji (Banerjee et al., 2012; Beula et al., 2012; Millon et al., 2012). Penelitian ini bertujuan untuk melakukan skrining herbal mangrove dan asosiasinya dari beberapa lokasi pertambakan di Sulawesi Selatan sebagai sumber penghasil bahan antioksidan yang dapat digunakan pada budidaya perikanan

\section{BAHAN DAN METODE}

Tanaman mangrove dan asosiasinya dikumpulkan dari beberapa daerah pertambakan di Sulawesi Selatan yaitu: Kabupaten Maros, Pangkep, Luwu Timur, Bone, dan Takalar, pada bulan Maret hingga Oktober 2014. Bagian tanaman yang diambil meliputi daun, bunga, buah, tangkai daun, batang, kulit batang, dan akar. Bagianbagian tanaman diambil menggunakan gunting tanaman, parang dan kampak, kemudian dimasukkan dalam kantong plastik hitam (Gambar1) selanjutnya dibawa ke Laboratorium Kesehatan ikan dan Lingkungan BPPBAP untuk proses analisis. Sebanyak 182 sampel telah berhasil dikumpulkan.

Tanaman mangrove dan asosiasinya diidentifikasi berdasarkan Kitamura et al. 1(998) dan Noor et al. (2006). Taman yang sudah dikumpulkan dibersihkan dan dipisahkan berdasarkan bagian-bagiannya, seperti, daun, bunga, buah, tangkai, daun, batang, kulit batang, dan akar, bergantung tanaman yang dikoleksi. Daun taman yang lebar terlebih dahulu diris kecil-kecil, buah, dan bunga dipisahkan, dipotong dan diiris, demkian pula dengan kulit batang terlebih dahulu diiris kecil-kecil sebelum dikeringakan (Gambar 2).

Bagian tanaman yang telah dipisahkan diletakkan pada baki palstik dan diberi kode (nomor secara berurut). Selanjutnya dikering-anginkan selama 2 minggu atau hingga kering bergantung jenis sampelnya. Biasanya bagian daun lebih cepat kering dibandingkan bagian lainnya, seperti buah, dan kulit batang (Gambar 3).

Setelah tanaman herbal kering selanjutnya dihaluskan menggunakan blender, dan diayak menggunakan ayakan/ saringan santan selanjutnya dimasukkan ke dalam kantong plastik klip. Selanjutnya diberi label atau kode seusai nomor urut tanaman pada saat pertama dikoleksi (Gambar 4).

Simplisia yang sudah tersedia ditimbang sebanyak 5 $\mathrm{g}$ (Gambar 5A) atau sesuai kebutuhan, dimasukkan dalam gelas Erlenmeyer atau botol duran. Selanjutnya diberi larutan methanol $80 \%$ dan diaduk dengan batang pengaduk sehingga seluruh permukaan simplisia terendam (Gambar 5B). Rendaman tersebut ditutup

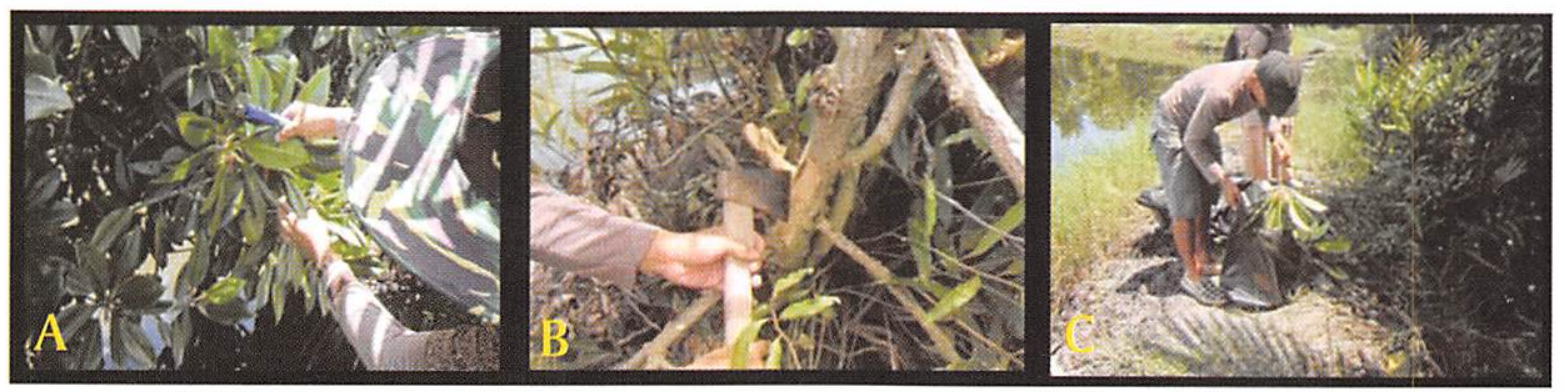

Gambar 1. (A) Penganmbilan daun tanaman menggunakan gunting, (B) pengambilan kulit batang tanaman menggunakan kapak, dan (C) tanaman dimasukkan dalam kantong plastik

Figure 1. Collecting of leaves of mangrove plants using scissors, (B) taking the bark of plants using axes, and (C) the plants put in a plastic bag 


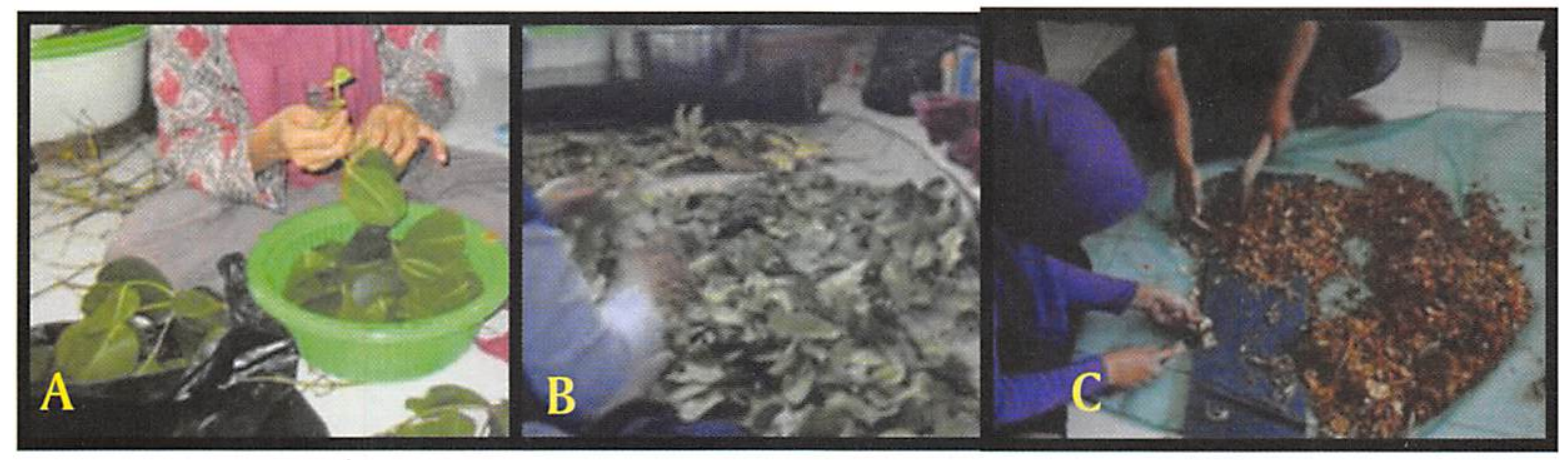

Gambar 2. Preparasi tanaman sebelum dikeringkan; (A) pemisahan daun dari tangkai daun, (B) daun yang lebar digunting kecil-kecil, (C) akar dan buah diiris kecil-kecil

Figure 2. Preparation of the plant before drying; (A) separation of the leaffrom petiole, (B) the width leaves sliced into small pieces, (C) the root and fruits sliced into small pieces

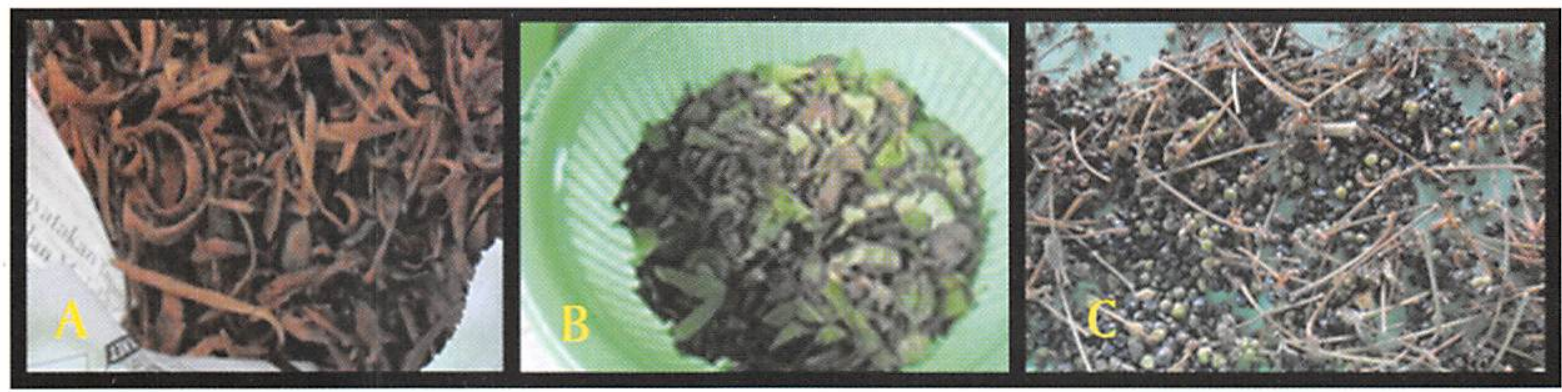

Gambar 3. Pengeringan tanaman, (A) buah mangrove yang telah diiris kecil, (B) daun mangrove, dan (C) buah tanaman asosiasi mangrove

Figure 3. Drying herb, (A) fruits of mangrove, (B) leaves of mangrove, (C) fruit of association plant

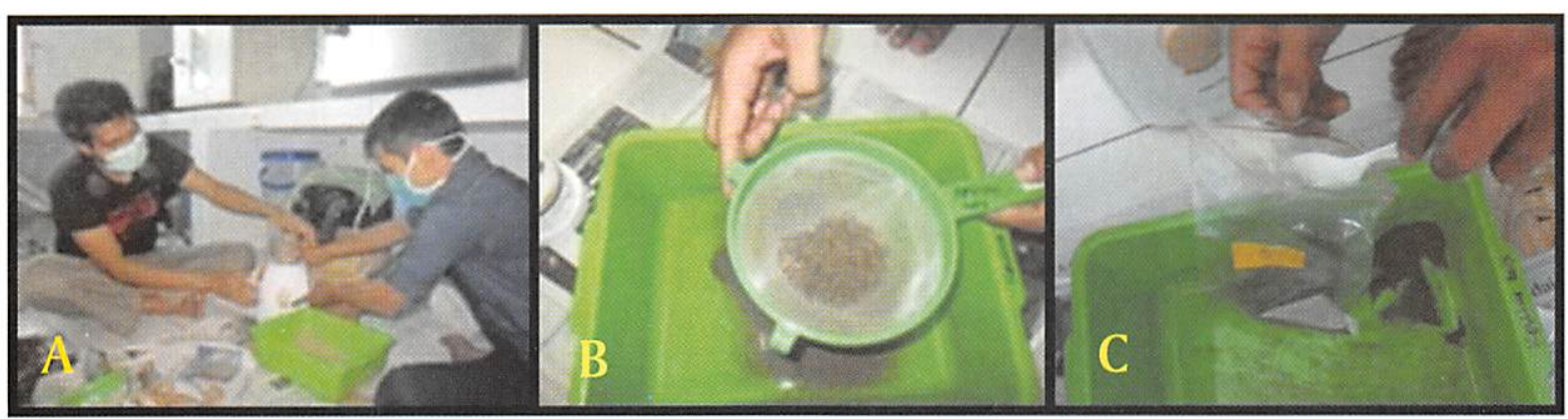

Gambar 4. Pembuatan simplisia bahan herbal, (A) herbal dihaluskan dengan blender, (B) tepung diayak dengan ayakan, dan (C) simplisia dimasukkan ke dalam plastik klip

Figure 4. Simplisia preparation of herb, (A) herb mashed in a blender, (B) flour sifted with a sieve, and (C) simplisia put in plastic clip

dengan aluminium foil dan didiamkan selama 24 jam, selanjutnya disaring dengan kain saringan (Gambar 5C) sehingga semua ampasnya tertahan dan yang lolos hanya cairan metanol yang sudah membawa bahan-bahan yang terlarut. Perendaman dilakukan selama 3 kali 24 jam dan setiap 24 jam dilakukan penyaringan atau bergantung tingkat kekeruhan rendaman, jika rendaman sudah terlihat jernih maka perendaman dihentikan. Hal ini dimaksudkan untuk memaksimalkan penarikan bahanbahan aktif tanaman oleh metanol. Hasil penyaringan tersebut kemudian disaring lagi dengan kertas saring yang menggunakan pompa vacum (Gambar 5D), kemudian cairannya ditampung dalam botol sampel atau botol duran untuk selanjutnya dikisat menggunakan Rotatory Evaporator:

Hasil ekstraksi tanaman herbal dalam larutan metanol selanjutnya dikisat dengan menggunakan Rotatory evaporator (Gambar 6). Larutan metanol diuapkan hingga tersisa bahan padatan dari bioaktif yang terkandung dalam tanaman. Jika pada saat dikeluarkan dari labu evaporator masih tersisa larutan metanol (belum terlalu kering) maka 

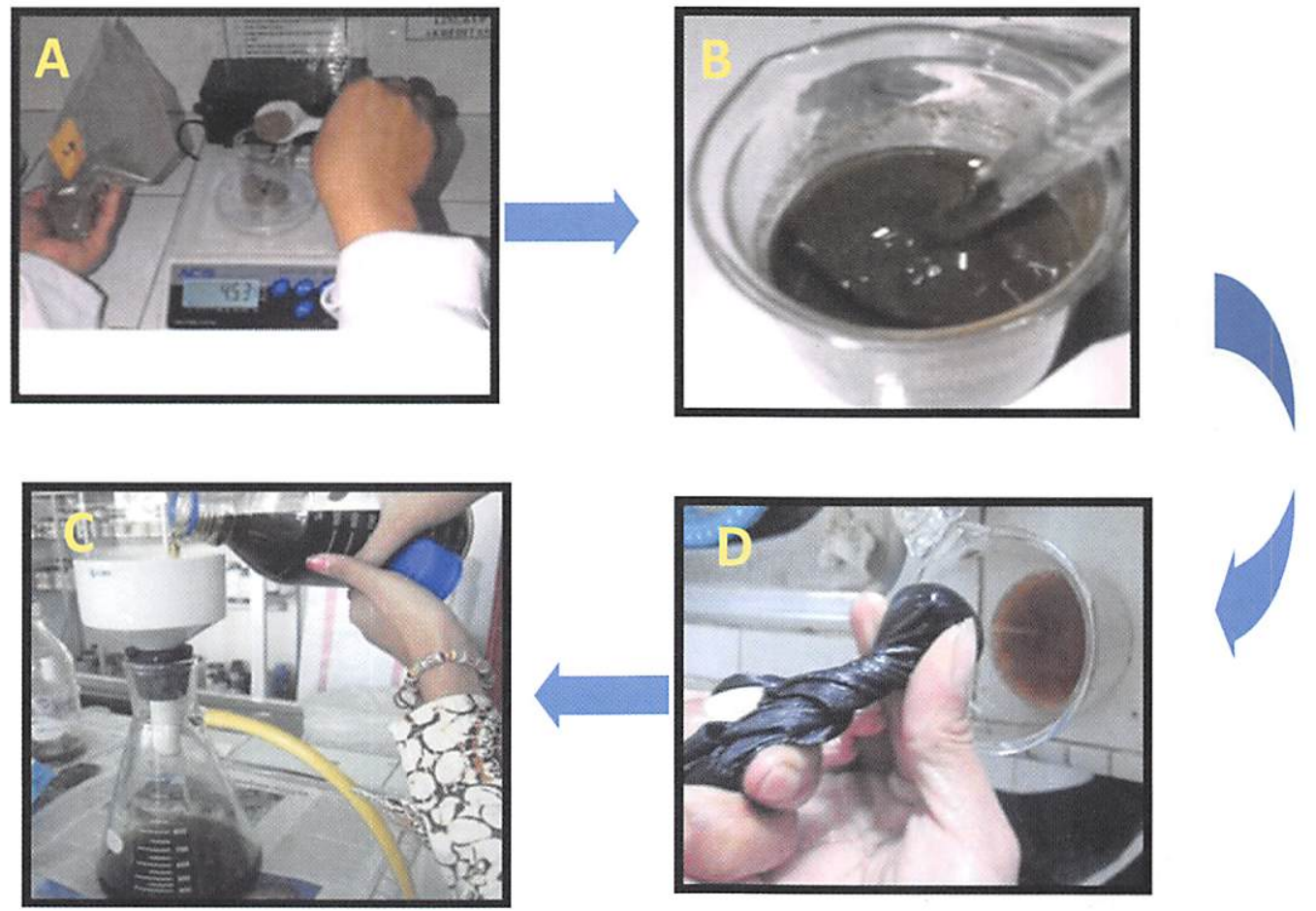

Gambar 5. Proses ekstraksi bahan herbal, (A) penimbangan simplisia, (B) perendaman dengan metanol $80 \%$, dan (C) penyaringan menggunakan kain saringan, (D) penyaringan menggunakan kertas saring

Figure 5. The process of extraction of herbal ingredients, $(A)$ weighing of simplisia, B) immersion with methanol of $80^{\circ}$ and (C) filtration using filter cloth, (D) filtering using a filter paper

penguapan dilanjutkan secara manual yaitu dengan cara botol yang berisi bahan aktif dengan ditutup dengan tissu, sehingga masih ada rongga udara dan metanol dapat menguap secara otomatis. Hal ini dilakukan hingga hasil pengkisatan benar-benar kering dan tidak ada lagi larutan metanol. Setelah metanol menguap hasil ekstraksi tersebut disimpan dalam kulkas suhu $4^{\circ} \mathrm{C}$.

Skrining bahan herbal mangrove dan asosiasinya sebagai penghasil bahan antioksidan dilakukan secara kualitatif dengan teknik "High Troughput Screening" (Kasanah \& Isnansetyo, 2013) menggunakan metode mikrowellplate assay. Standar yang digunakan adalah Vita- min C (asam ascorbit), sedangkan untuk mengevaluasi aktivitas free radical scavening (antioksidan) dari ekstrak mangrove digunakan DPPH (C10H12N5O6). Metode ini didasarkan pada reaksi antioksidan dengan radikal stabil dalam larutan alkohol. Ekstrak metanol dari tanaman mangrove dan asosiasi ditimbang sebanyak $10 \mathrm{mg}$, selanjutnya dilarutkan dalam $100 \mathrm{~mL}$ DMSO 10\%. DPPH dibuat larutan dengan menimbang $80 \mathrm{mg}$ kemudian dilarutkan $100 \mathrm{~mL}$ metanol. Sebanyak $25 \mu \mathrm{L}$ larutan ekstrak dimasukkan ke dalam mikrowell plate, setiap jenis ekstrak diulang 3 kali. Selanjutnya diberi larutan DPPH sebanyak $25 \mu \mathrm{L}$. Mikrowel plate dibiarkan selama 30 menit

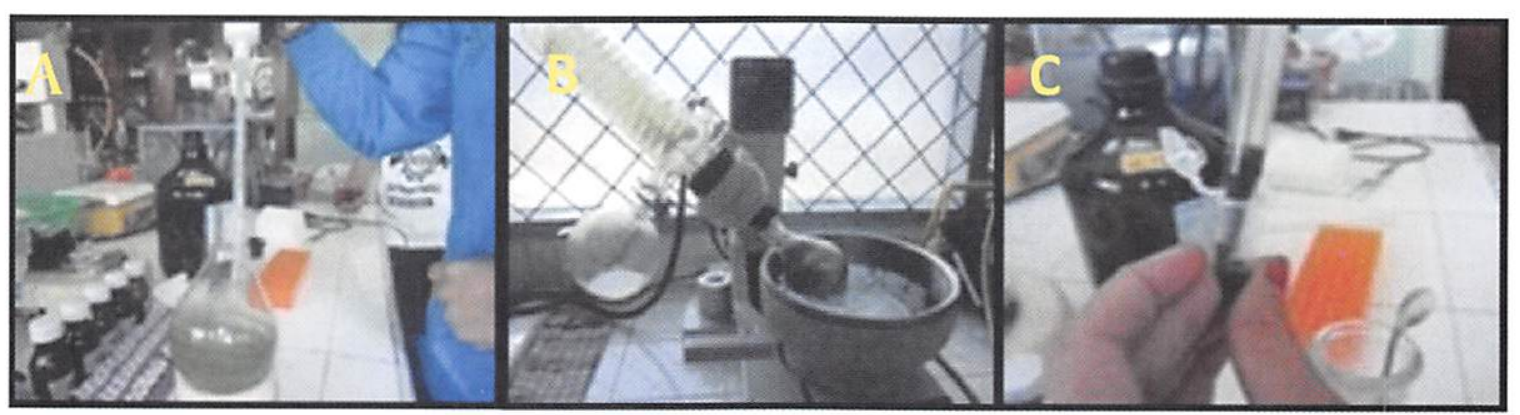

Gambar 6. Evaporasi hasil ekstraksi bahan herbal, (A) hasil ekstraksi dimasukkan dalam labu evaporator, (B) penguapan metanol dengan evaporasi, dan $(C)$ hasil evaporasi dimasukkan dalam tabung mikro

Figure 6. Evaporation of extracted herbal ingredients, (A) the extraction put in to the evaporator flask, (B) the evaporation of methanol by evaporation, and (C) The crude extract put in to the micro tube 
agar terjadi reaksi, selanjutnya diamati perubahan warnanya. Keberadaan senyawa antioksidan dalam ekstrak mangrove dan tanaman asosiasinya ditandai dengan adanya perubahan reaksi warna pink menjadi kuning (Gambar 7).

Seluruh data yang dikumpulkan kemudian dianalisis secara deskriptif yang disajikan dengan bentuk tabel.

\section{HASIL DAN BAHASAN}

Antioksidan merupakan molekul yang dapat menghambat proses oksidasi suatu molekul. Proses oksidasi menghasilkan radikal bebas yang dapat menyebabkan kerusakan bahkan kematian sel. Antioksidan bisa berasal dari vitamin $A$ dan vitamin $C$ atau secara alami dari tanaman yang mengandung antioksidan seperti mangrove dan asosiasinya. Hasil uji aktivitas antioksidan secara kualitatif menunjukkan bahwa dari 182 sampel, $104(57,14 \%)$ sampel di antaranya positif mengandung antioksidan. Dari 104 sampel yang positif mengandung antioksidan, 65 sampel $\left(62,50^{\circ}\right)$ adalah tanaman mangrove dan 39 sampel $(37,50 \%)$ adalah tanaman asosiasi mangrove. Beberapa hasil penelitian sebelumnya menunjukkan bahwa tanaman mangrove sangat potensial sebagai penghasil antioksidan (Banerjee et al., 2012; Beula et al., 2012; Millon et al., 2012). Abed et al. (2013) melaporkan bahwa tanaman Rhizophoraceae banyak mengandung antioksidan, sedangkan Putri et al. (2013) telah meneliti kandungan antioksidan pada daun dan buah nipah.

\section{Hasil Uji Antioksidan Tanaman Mangrove dan Asosiasinya dari Kabupaten Maros}

Hasil uji antioksidan terhadap 51 sampel yang dikumpulkan dari daerah pertambakan di Kabupaten Maros, menunjukkan bahwa sebanyak 21 sampel $(41,2 \%)$ positif mengandung antioksidan. Dari 21 sampel tersebut 10 sampel adalah tanaman mangrove dan 11 sampel adalah tanaman asosiasi mangrove (Tabel 1).

\section{Uji Antioksi dan Tanman Mangrove dan}

Asosiasinya dari Kabupaten Pangkep

Hasil uji antioksidan tanaman mangrove dan asosiasinya yang dikumpulkan dari Kabupaten Pangkep disajikan pada Tabel 2. Dari sebanyak 67 sampel yang telah diuji aktivitas antioksidannya diperoleh sampel $(50,75 \%)$ di antaranya positif mengandung antioksidan. Dari 34 sampel tersebut 19 sampel adalah tanaman mangrove dan 15 sampel adalah tanaman asosiasinya (Tabel 2).

\section{Uji Antioksidan Tanaman Mangrove dan Asosiasinya dari Kabupaten Luwu Timur}

Hasil uji antioksidan terhadap 22 sampel yang diambil dari Kabupaten Luwu Timur menunjukkan bahwa
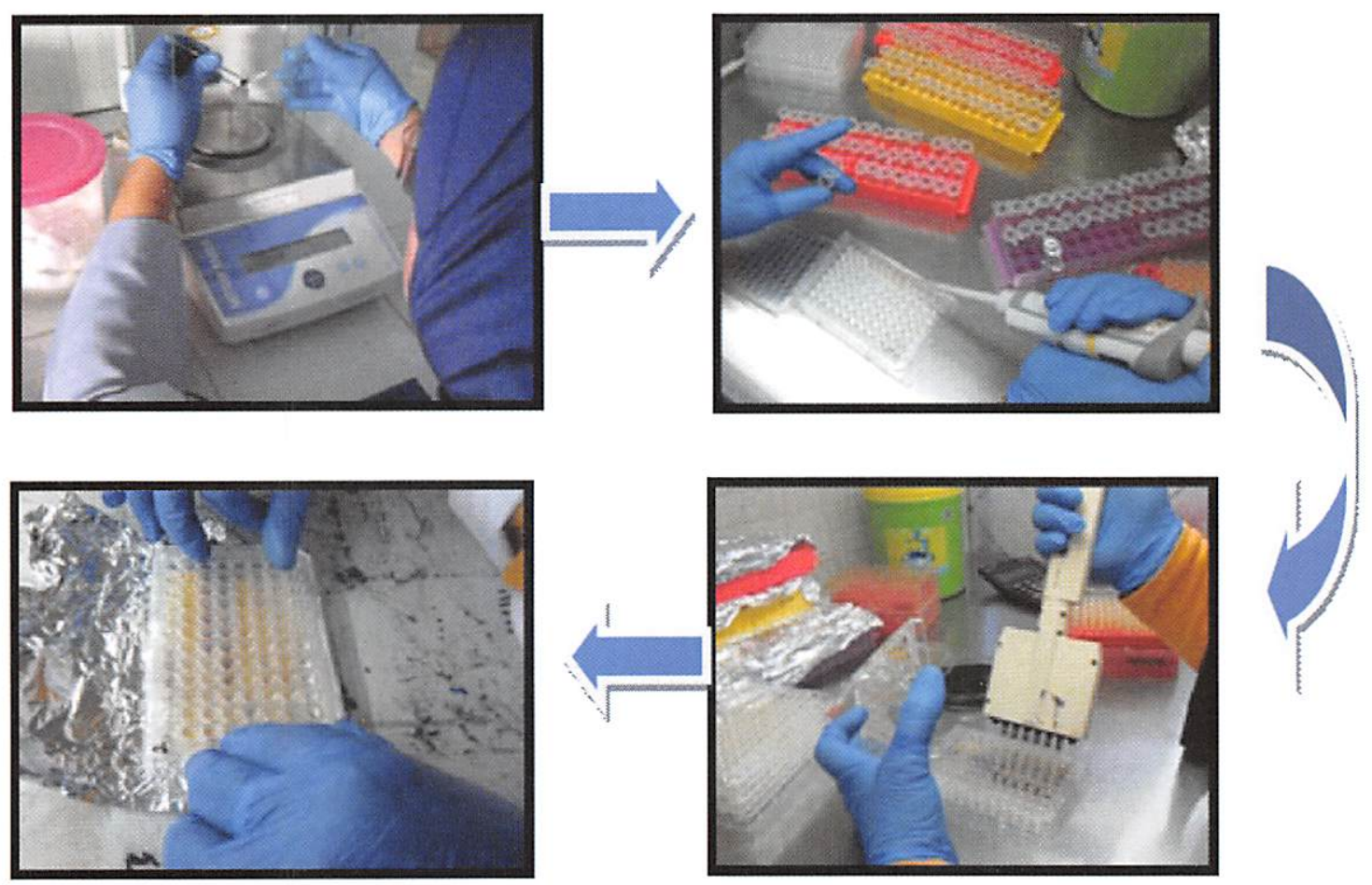

Gambar 7. Uji aktivitas antioksidan pada beberapa ekstrak kasar (ekstrak metanol) mangrove dan asosiasinta, penimbangan ekstrak metanol, (B) ekstrak mangrove dimasukkan dalam mikrowell plate, (C) pemberian larutan DPPH, (D) pengamatan perubahan warna setelah diinkubasi

Figure 7. Antioxidants activity test in some crude extracts (methanol extract) of mangrove and mangrove association plants, (A) weighing the methanol extract, (B) extracts of mangrove put in to the mikrowell plate, (C) the provision of DPPH solution, (D) observation of the color change after incubated 
Tabel 1. Hasil uji aktivitas antioksidan ekstrak metanol herbal mangrove dan asosiasinya yang dikumpulkan dari Kabupaten Maros

Table 1. Antioxidant activity test result of methanol extract of mangrove and association plants collected from Maros Regency

\begin{tabular}{lccc}
\hline \multicolumn{1}{c}{ Jenis tanaman } & Jumlah sampel & Positif & Negatif \\
\hline Mangrove & 14 & 10 & 4 \\
Asosiasi Mangrove & 37 & 11 & 26 \\
\hline Jumlah & 51 & 21 & 30 \\
\hline
\end{tabular}

Tabel 2. Hasil uji antioksidan ekstrak metanol herbal mangrove dan asosiasinya yang dikumpulkan dari Kabupaten Pangkep

Table 2. Antioxidant activity test result of methanol extract of mangrove and association plants collected from Pangkep Regency

\begin{tabular}{lccc}
\hline \multicolumn{1}{c}{ Jenis tanaman } & Jumlah sampel & Positif & Negatif \\
\hline Mangrove & 25 & 19 & 6 \\
Asosiasi Mangrove & 42 & 15 & 27 \\
\hline Jumlah & 67 & 34 & 33 \\
\hline
\end{tabular}

sebanyak $17(77,72 \%)$ sampel positif mengandung antioksidan (Tabel 3). Pada Tabel 3 terlihat pula bahwa dari 17 sampel yang mengandung antioksidan, 9 sampel di antaranya adalah tanaman mangrove dan $8 \mathrm{di}$ antaranya adalah tanaman asosiasinya.

\section{Uji Antioksidan Tanaman Mangrove dan Asosiasinya dari Kabupaten Takalar}

Hasil uji aktivitas antioksidan terhadap sampel tanaman mangrove dan asosiasinya yang diambil dari Kabupaten Takalar disajikan pada Tabel 4. Pada Tabel 4 terlihat bahwa semua sampel mangrove positif mengandung antioksidan, sedangkan tanaman asosiasinya hanya dua sampel yang positif antioksidan dari tiga sampel yang diambil.

\section{Uji Antioksidan Tanaman Mangrove dan} Asosiasinya dari Kabupaten Bone

Hasil uji antioksidan tanaman mangrove dan asosiasinya yang diambil dari Kabupaten Bone disajikan pada Tabel 5. Pada Tabel 5 terlihat bahwa sebanyak 32 sampel yang telah diuji aktivitas antioksidannya dan 26 $(81,25 \%)$ sampel di antaranya positif mengandung antioksidan. Dari 26 sampel tersebut 23 sampel adalah tanaman mangrove dan tiga sampel adalah tanaman asosiasinya. Kurangnya jumlah sampel asosisasi man-

Tabel 3. Hasil uji antioksidan ekstrak metanol herbal mangrove dan asosiasinya yang dikumpulkan dari Kabupaten. Luwu Timur

Table 3. Antioxidant activity test result of methanol extract of mangrove and association plants collected from Luwu Timur Regency

\begin{tabular}{lccc}
\hline \multicolumn{1}{c}{ Jenis tanaman } & Jumlah sampel & Positif & Negatif \\
\hline Mangrove & 13 & 9 & 4 \\
Asosiasi Mangrove & 9 & 8 & 1 \\
\hline Jumlah & 22 & 17 & 5 \\
\hline
\end{tabular}

Tabel 4. Hasil uji antioksidan ekstrak metanol herbal mangrove dan asosiasinya yang dikumpulkan dari Kabupaten Takalar

Table 4. Antioxidant activity test result of methanol extract of mangrove and association plants collected from Takalar Regency

\begin{tabular}{lccc}
\hline \multicolumn{1}{c}{ Jenis tanaman } & Jumlah sampel & Positif & Negatif \\
\hline Mangrove & 5 & 5 & 0 \\
Asosiasi Mangrove & 3 & 2 & 1 \\
\hline Jumlah & 8 & 7 & 1 \\
\hline
\end{tabular}


Tabel 5. Hasil uji antioksidan ekstrak metanol herbal mangrove dan asosiasinya yang dikumpulkan dari Kabupaten Bone

Table 5. Antioxidant activity test result of methanol extract of mangrove and association plants collected from Bone Regency

\begin{tabular}{lccc}
\hline \multicolumn{1}{c}{ Jenis tanaman } & Jumlah sampel & Positif & Negatif \\
\hline Mangrove & 23 & 18 & 5 \\
Asosiasi Mangrove & 9 & 8 & 1 \\
\hline Jumlah & 32 & 26 & 6 \\
\hline
\end{tabular}

grove yang negatif antioksidan pada sampel yang diambil dari Kabupaten Bone disebabkan jumlah sampel tanaman asosiasi mangrove juga sedikit dibanding tanaman mangrovenya yaitu hanya tiga sampel dari 32 total sampel dan ketiga sampel tersebut positif mengandung antioksidan.

\section{KESIMPULAN}

Hasil penelitian ini menunjukkan bahwa tanaman mangrove dan asosiasinya sangat berpotensi sebagai penghasil antioksidan. Jumlah sampel mangrove dan asosiasinya yang positif mengandung antioksidan tertinggi diperoleh dari Kabupaten Pangkep, kemudian diikuti Kabupaten Bone, Kabupaten Maros, Kabupaten Luwu Timur, dan KabupatenTakalar. Tanaman mangrove memiliki potensi antioksidan lebih tinggi dai asosiasinya.

\section{UCAPAN TERIMA KASIH}

Penulis mengucapkan terima kasih kepada rekanrekan peneliti dan teknisi yang penuh dedikasi dan tanggung jawab dalam membantu pelaksanaan penelitian ini. Penelitian ini dibiayai dari dana DIPA BPPBAP Maros tahun 2014.

\section{DAFTARACUAN}

Abed, S.A., Sirat, H.M., \& Taher, M. (2013). Total phenolic, Antioxidant, antimicrobial activities and toxicity study of Gynotroches axillaris blume (Rhizophoraceae). EXCLI Journal. (12), 404-412.

Banerjee 1, M.B., Ravikumar, S., Gnanadesigan, M., Rajakumar, B., \& Anand, M. (2012). Antiviral, antioxidant and toxicological evaluation of mangrove associate from South East coast of India. Asian Pacific journal of Tropical Biomedicine, S1775-S1779.

Baskaran, R., \& Mohan, P.M. (2012). In vitro antibacterial activity of leaf extracts of Rhizophora mucronata $L$. against multi drug resisten Vibrio spp. isolated from marine water lobster's larvae hatcheries. Indian Journal of Geo-Marine Science. 41(3), 218-222.

Beula, J. M., Gnanadesigan, M., Rajkumar, P.B., Ravikumar, S., \& Anand, M. (2012). Antiviral, antioxidant and toxicological evaluation of mangrove plant from South East coast of India. Asian Pacific journal of Tropical Biomedicine, S352-\$357.

Chakraborty, S., \& Ghosh, U. (2014). In Vivo Immunological changes occurring at different time intervals in white spot syndrome virus infected shrimp, treated with antiWSSV drug drived from marine plants. International Journal of Basic and Applied Virology, 3 (1), 01-15.

Chakraborty, S., Ghosh, U., Balasubramanian, T., \& Das, P. (2014). Screening, isolation and optimization of antwhite spot yndrome virus drug derived from marine plants. Asian Pacific Journal of Tropical Biomedicine, S107S117.

Kasanah, N., \& Isnansetyo, A. (2013). High Throughput Screening dan Bioassay dalam Penemuan senyawa Bioaktif dari Alam. Materi workshop dan Pelatihan Bioprospekting Bahan Alam Kelautan II. Laboratorium Hidrobiologi. Jurusan Perikanan. Fakultas Pertanian. Universitas Gadjah Mada, $22 \mathrm{hlm}$.

Kitamura, S., Anwar, C. , Chaniago, A., \& Baba, S. (1998). Hand book of mangrove in Indonesia, Bali \& Lombok, $58 \mathrm{pp}$.

Millon, M.A., Muhit, M.A., Goshwami, D., Masud, M.M., \& Begum, B. (2012). Antioxidant, cytotoxic and antimicrobial activity of Sonneratia alba bark. IJPSR, 3 (7), 2233-2237.

Muliani, Suryati, E., Tenriulo, A., \& Nurbaya. (2005). Pengaruh Penggunaan Ekstrak Daun Kopasanda Euphatorium inulifolium terhadap Populasi V. harveyi dan Sintasan Pascalarva Udang Windu Penaeus monodon. Prosiding Konferensi Nasional Akuakultur.

Mulyani, Y., Bachtiar, E., \& Kurnia, A.M.U. (2013). Peranan Senyawa Metabolit Sekunder Tumbuhan Mangrove Terhadap Infeksi Bakteri Aeromonas hydrophila pada Ikan Mas (Cyprinus carpio L). Universitas Padjajaran. Bandung. Jurnal Akuatika, 4 (1), 1-9.

Noor, Y.R., Khazali, M., \& Suryadiputra, I.N.N. (2006). Panduan Pengenalan Mangrove di Indonesia. Ditjen. PHKA. Wetlands International-Indonesia Programme, $220 \mathrm{hlm}$.

Putri, I.J., \& Fauziyah, E. 2013. Aktivtas antioksidan daun dan buah nipah (Nypa fruticans) asal Banyuasin Sumatra Selatan dengan Metode DPPH. Maspari Journal, 5(1), 16-21.

Revathi, P., Senthinath, T.J., Thirumalaikolundusubramanian, P., \& Prabhu, N. (2013). Medicinal properties of mangrove plants-an overview. Int.J. Bioassays, 02(12),15971600.

Sasidhar, K., Tirupathi, Ch, Vishnuvardhan, Z., \& Krishna, R.H. (2013). A Review on Chemistry of Mangrove Plants and Prospects of Mangroves as Medicinal Plants. IJGHC, 2(4), 943-953. 